\title{
Effects of Trehalose on Flower Senescence from the View Point of Physical States of Water
}

\author{
Mari Iwaya-InOue and Hiroshi Nonami* \\ Laboratory of Crop Science, Department of Plant Resource, Faculty of Agriculture, \\ Graduate School, Kyushu University, Fukuoka 812-8581, Japan \\ * Plant Biophysics/Biochemistry Research Laboratory, Faculty of Agriculture, \\ Ehime University, Matsuyama 790-8566, Japan
}

(Received December 10, 2002)

\begin{abstract}
A role of trehalose on physical states of water in cut bulbous flowers was determined by ${ }^{1} \mathrm{H}-\mathrm{NMR}$ spectroscopy and the isopiestic psychrometer. Treatments with 100 and 50 $\mathrm{mM}$ trehalose markedly prolonged vase-life in gladiolus and tulip cut flowers, respectively. Trehalose maintained a higher degree of the water content accompanying with suppressing protein degradation and membrane integrity than the control tissues. The long fraction of spin-lattice relaxation time $\left(T_{1}\right)$ of the intracellular water in both tissues indicated that trehalose functioned to protect vacuolar water. Furthermore, trehalose affected to enhance water uptake into tepal tissues though not to promote cell elongation and not to cause osmotic adjustment with maintaining a high level of turgor. On the other hand, the short fraction of spin-spin relaxation time $\left(T_{2}\right)$ estimated as bound water suggested that cytoplasmic water was also maintained. From these results, it suggests that trehalose does not act as an energy source nor directly participate in osmotic adjustment and these characteristics distinguish it from other sugars such as sucrose. In cut gladiolus and tulip flowers trehalose played an important role to prevent loss of water determined by $T_{1}, T_{2}$ and turgor measurements.
\end{abstract}

Keywords : flower senescence, ${ }^{1} \mathrm{H}-\mathrm{NMR}$ relaxation times $\left(T_{1}, T_{2}\right)$, trehalose, turgor, water compartments

\section{INTRODUCTION}

Senescence can be broadly defined as the combination of events that lead to the death of cells. The functional life of the flower is terminated by senescence and/or abscission. Multiple processes contribute to produce the visible signs of petal wilting and inrolling that typify senescence. Flower senescence is accompanied by an increased respiration activity in daylily and chrysanthemum petals (Bieleski and Reid, 1992; Elanchezhian and Srivastava, 2001), a decreased protein content or an increased protease activity in daylily, rose, Sandersonia aurantiacaca and Alstroemera sp. petals (Guerrero et al., 1998 ; Panavas et al., 1998 ; Torre et al., 1999; Eason et al., 2002; Wagstaff et al., 2002) and reduced lipid fluidity of the membranes in rose (Itzhaki et al., 1990; Torre et al., 1999). Furthermore, Borochov et al. (1997) suggested a decline in the content of membrane components such as phospholipids in petunia flower senescence.

In cut flowers the process of senescence has been reported to be delayed by various

Corresponding author: Mari Iwaya-Inoue, e-mail : mariino@agr.kyushu-u.ac.jp 
chemicals. A treatment of cycloheximide, an inhibitor of protein synthesis on the $60 \mathrm{~S}$ ribosome, was also shown to prolong the vase life of the daylily (Hemerocallis hybrid) flowers and prevent protein loss from the petals (Panavas et al., 2000 ; Mahagamasekera and Leung, 2001). Furthermore, cycloheximide and 6-methylpurine were the most effective and inhibited inrolling almost completely in ethylene-sensitive carnation (Dianthus caryophyllus $\mathrm{cv}$.) flower petals (Taverner et al., 2000). Ethylene is a stimulating factor of senescence. Silver thiosulfate (STS) binds competitively to the ethylene binding site, and thus, markedly prolonged vase life of ethylene-sensitive flowers such as petunia and sweet pea (Reid and $\mathrm{Wu}, 1992$; Borochov et al., 1997; Ichimura and Hiraya, 1999).

On the other hand, sucrose feeding of individual flowers also delayed Sandersonia aurantiaca tepal senescence and altered amino acid metabolism (Eason et al., 2000). These results suggested that sucrose functions as an energy source for respiration. Alternatively, carbohydrates were reported as osmolytes to maintain water balance and as substrates for structural materials in cut flowers (Halevy and Mayak, 1979: references therein). Sucrose treatment of cut gladiolus flowers increased the spike quality but did not demonstrate any drastic effects on vase-life (Bravdo et al., 1974; van Doorn, 1997: references therein). Trehalose (1- $\alpha$-D-glucopyranosyl- $\alpha$-D-glucopyranoside), a disaccharide consisting of two $\alpha$-linked glucose units, has been reported to enhance tolerance against desiccation and high temperature, probably by protecting membranes and enzymes from various stresses (Crowe et al., 1984, 1998; Lee et al., 1989; Hottinger et al., 1994). Trehalose is widely available in bacteria, fungi, algae, insects and various invertebrates (Elbein, 1974). However, most plants do not accumulate trehalose with the desert resurrection plants such as Selaginella lepidophylla and Myrothamnus flabellifolius Welw., being a notable exception (Bianchi et al. 1993; Drennan et al. 1993). Arabidopsis thaliana and Selaginella lepidophylla contain genes homologous with the trehalose-6-phosphate synthase (TPS) genes of bacteria and fungi (Van Dijck, 2002). Recent studies have shown that trehalose plays a protective role in yeast in a variety of stresses, including heat, freezing and thawing, dehydration, hyperosmotic shock and oxidant injury (Hottinger et al., 1994; Felix, et al. 1999; Sano et al., 1999). Trehalose accumulates dramatically in microorganisms during heat shock and osmotic stress and helps protect cells against thermal injury and oxygen radicals. After "cold shock," trehalose levels in a Escherichia coli strain increased up to 8-fold (Kandror et al., 2002). Further, transgenic tobacco plants, which produce trehalose as a result of the introduction of genes encoding trehalose-synthesizing enzymes, showed normal growth performance under drought stress compared with that of wild-type tobacco plants (Holmström et al., 1996). It is suggested that, in phospholipid bilayers, trehalose binds directly to the surface of the membrane in place of bound water molecules (Crowe et al., 1987; Hanamura et al., 1998).

In petal parenchyma cells, the volume of water occupies $90 \%$ or over. In general, petal senescence is accompanied by a decrease in the water content (van Doorn, 1997). However, there have been few reports about the role of water in the senescence process. Since many metabolic processes occur in aqueous solution in cells, the water status in living tissues is considered to play an important role in their physiological condition. Nuclear magnetic resonance (NMR) can be demonstrated to detect the state of water. Spin-lattice $\left(T_{1}\right)$ and spin-spin $\left(T_{2}\right)$ relaxation times indicate the water status in tissues since they reflect the motion of water molecules. NMR has been applied to the studies of higher plant tissues that are exposed to environmental or biological stress (Kaku and Iwaya-Inoue, 1990 ; Iwaya-Inoue et al., 1993; Kaku, 1993). Moreover, there are several compartments within a cell divided by biomembranes. Water in different subcellular organelles is often characterized by different proton relaxation times. In the previous reports, $T_{1}$ and $T_{2}$ have been used to detect water components of soybean seeds (Ishida et al., 1987), apple tissues (Snaar and Van As, 1992) and 
in rabbit brain (Sulyok et al., 2001). The distribution of water proton relaxation times can therefore provide quantitative information about water compartmentation.

This paper presents changes in the physical states of water, such as NMR relaxation times and turgor in gladiolus petals and tulip tepals as ethylene-insensitive cut flowers. In particular, a possible role of trehalose in regulating the water status in relation to protein contents and membrane integrity is discussed.

\section{PROMINENT EFFECTS OF TREHALOSE ON WILTING OF CUT FLOWERS DURING SENESCENCE}

The 1 st and the 2 nd florets of gladiolus flower stalk were fully opened at $1 \mathrm{~d}$ (day(s) after harvest), and approximately two additional florets opened fully per day. The 1st florets wilted and the color of its petals changed from white to brown in the stalks that are placed in distilled water (control) within $4 \mathrm{~d}$ (Otsubo and Iwaya-Inoue, 2000). In contrast to gladiolus flowers, which have green sepals, those of tulip have no sepals, and in such flowers the perianth parts are termed "tepals." The tulip flower consists of three outer tepals and three inner ones. The cut tulip flower opened $1 \mathrm{~d}$ after treatment and the tepal color changed from red to dark after $7 \mathrm{~d}$ in distilled water. These bulbous flowers are generally considered to ethyleneinsensitive, as application of exogenous ethylene has little effects (Woltering and van Doorn, 1988).

It has been reported that cycloheximide, a protein biosynthesis inhibitor, was the most effective and inhibited inrolling almost completely in ethylene-sensitive carnation (Dianthus caryophyllus cv. White Sim) flower petals (Taverner et al., 2000). Furthermore, DNA breakage and activities of nucleases in daylily petals (Hemerocallis hybrid cv. Stella d'Oro), as an ethylene-insensitive flower, occur later when senescence is retarded by cycloheximide (Panavas et al., 2000). In our experiment, $0.1 \mathrm{~mm}$ cycloheximide was effective against wilting of the 1st floret in gladiolus spikes (Otsubo and Iwaya-Inoue, 2000). However, this substance completely inhibited petal expansion of the 3rd, 4th and 5th florets on the spikes. Furthermore, in Alstroemeria, a Liliaceous species as an ethylene-sensitive plant, there was a dramatic increase in the expression of a putative cysteine protease (ALSCYP1) indicating that this gene may encode an important enzyme for the proteolytic process during development and senescence (Wagstaff C. et al., 2002). However, the 1st floret wilted and browned on the whole gladiolus spike treated with $0.2 \mathrm{~mm}$ iodoacetic acid or $0.1 \mathrm{~mm}$ phenylmethylsulfonyl fluoride (PMSF), inhibitors of cysteine- or serine-protease, respectively; the same period of senescence observed for the control spikes (Otsubo and Iwaya-Inoue, 2000). Furthermore, fusicoccin, which increases stomatal opening by activating the plasma membrane $\mathrm{H}^{+}$-ATPase (Marre, 1979), was used as an inhibitor of stomatal closing to determine whether those closing after full unfolding of petal was involved in the wilting of gladiolus petals. As a result, $5 \mu \mathrm{M}$ fusicoccin caused more severe wilting.

On the contrary, $100 \mathrm{~mm}$ trehalose remarkably suppressed water loss and enhanced vase-life in petals of cut gladiolus spikes, whereas the other mono- and di-saccharides had no effects. Further, $50 \mathrm{~mm}$ trehalose with $50 \mu \mathrm{M}$ chloramphenicol (CAP), a germicide (hereafter called the trehalose treatment), notably suppressed tulip tepal wilting than did the other inhibitors (Iwaya-Inoue and Takata, 2001). In addition, the control tulip flowers showed $60 \%$ of tepal abscission while the trehalose treatment showed a $4 \%$ abscission ratio.

\section{PHYSICAL STATES OF WATER IN TREHALOSE-TREATED CUT FLOWERS}

It has been reported that chrysanthemum flowers showed the maximum protease activity 
and a high decline in fresh mass and the relative water content with flower senescence (Elanchezhian and Srivastava, 2001). First of all, the relative water contents of the cut flower tissues were measured in order to determine their degree of wilting quantitatively. The water content of florets remained relatively constant for the first $2 \mathrm{~d}$, but after that decreased drastically in the control spikes (Iwaya-Inoue et al., 2000). The first $3 \mathrm{~d}$ after harvest, there was a significant difference in the wilting scores among the sugar treatments. On the $3 \mathrm{rd} \mathrm{d}$, the water contents of the 1 st florets were $4.6,3.8$, and $5.9 \mathrm{~g} \cdot \mathrm{g}^{-1}$ dry matter in spikes treated with maltose, sucrose, and glucose at $0.1 \mathrm{M}$, respectively, all of which were much lower than the water content of the control. On the other hand, the water content of the 1st floret of trehalose-treated spikes was $11.1 \mathrm{~g} \cdot \mathrm{g}^{-1}$ dry matter, approximately twice that of the florets treated with the other sugars. Changes in dry weights of the florets showed a similar tendency, but the water content of the control floret decreased to less than $50 \%$ of that in the trehalose-treated floret by the 4 th $\mathrm{d}$. These results suggest that trehalose specifically enhanced water uptake into petals and maintained a higher degree of turgor in the petals than do the other sugars. Similar effects were observed in tulip cut flowers treated with trehalose (Iwaya-Inoue and Takata, 2001). Thus, trehalose maintained a higher degree of the water content in gladiolus petals and tulip tepals than do the control during senescence.

In order to elucidate the effect of trehalose on physical states of water in these flowers, ${ }^{1} \mathrm{H}$ NMR relaxation behavior and turgor were determined. A peak of ${ }^{1} \mathrm{H}-\mathrm{NMR}$ spectra observed at around $4.8 \mathrm{ppm}$ in chemical shift corresponds to that from ${ }^{1} \mathrm{H}$ nuclei of water. The ${ }^{1} \mathrm{H}-\mathrm{NMR}$ spectral recovery of the gladiolus petals and tulip tepals changed and the proton relaxations did not occur uniformly during senescence. If a single nuclear environment exists, plots of signal intensity will be a single exponential. However, semi-log plots of ${ }^{1} \mathrm{H}-\mathrm{NMR}$ signal intensity of these tissues were multi-exponential and showed that there were several components in water proton mobility. McCain et al. (1984) proposed that several compartments are the water signal in leaf cells to the orientation of chloroplasts that have thylakoid membranes. It is generally accepted that cellular water exists in two to three components shown by NMR relaxation times (Ishida et al., 2000). As shown in Fig. 1, water components consist of three water status such as free water, loosely bound water and tightly bound water in a plant cell. The three compartmentation of water with different relaxation times, originated from vacuole, cytoplasm and cell wall/extracellular space (apoplast), were identified in the parenchyma tissue of apples (Snaar and Van As, 1992 ; Hills and Remigereau, 1997). Ishida et al. (1987) stated that free water indicating the longest $T_{1}$ component in plant cells was derived from vacuoles. Thus, differences in the relaxation times $\left(T_{1}, T_{2}\right)$ of biological tissues are interpreted as the differences of the ratio of "free water" to "bound water." Several components of $T_{1}$ for the gladiolus and tulip flower tissues detected by the inversion recovery method were calculated from semi-log plots of ${ }^{1} \mathrm{H}-\mathrm{NMR}$ signal intensities by a curve fitting (Iwaya-Inoue et al. 1999, 2000). The method revealed that water in the tissues consisted of at least two water components with $T_{1}$ values ranging about $1.5 \mathrm{~s}$ (long $T_{1}$ component) and about $0.2 \mathrm{~s}$ (short $T_{1}$ component). In the petal of the control gladiolus spikes, the long $T_{1}$ component was a major fraction showing about $65 \%$ on the 1 st $d$. At senescent stage ( 3 to $4 \mathrm{~d}$ ), the long $T_{1}$ fraction markedly decreased to the half of the value on the 1 st $\mathrm{d}$. On the other hand, in the petals of trehalose-treated spikès, the long $T_{1}$ fraction was the major component showing about $85 \%$ on the $1 \mathrm{~d}$, and it had been retained over $60 \%$ at $4 \mathrm{~d}$. Additionally, the long $T_{1}$ fraction decreased to about $0.9 \mathrm{~s}$ at $7 \mathrm{~d}$ after treatment in the control tulip tepal tissues (Iwaya-Inoue et al. 2000). The long fraction in the trehalose-treated tepals maintained the initial $T_{1}$ values indicating about $1.2 \mathrm{~s}$. These parenchyma cells in both petal and tepal tissues were almost occupied with vacuoles, according to the microscopic observation. From these results, trehalose would sustain free water in the florets. Then, turgor was calculated by 


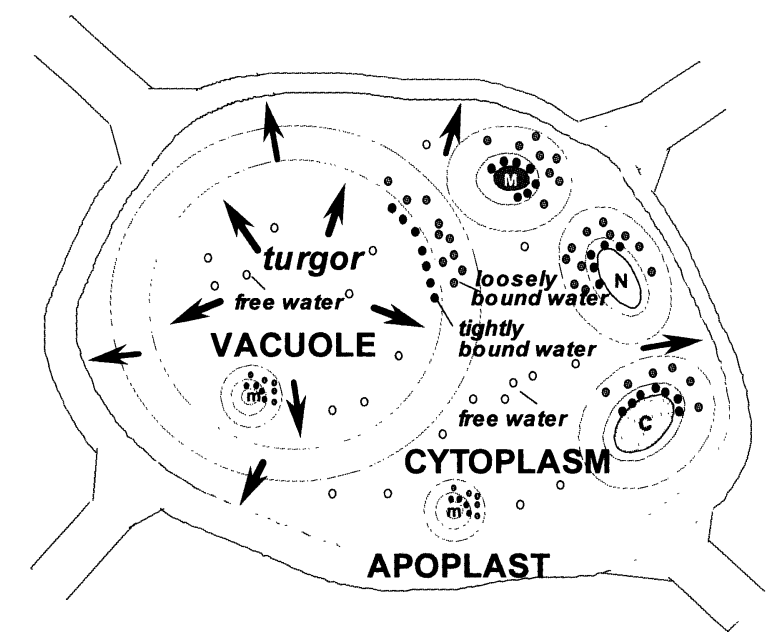

Fig. 1 A schematic diagram of water compartmentation in a plant cell. Closed small circles ( ), tightly bound water; closed small gray circles (5), loosely bound water; open small circles $(\bigcirc)$, free water. Layers of the tightly bound water molecules and loosely bound water molecules are shown in the surroundings of biomembranes and macromolecules. The water molecules and water layers existing inner membrane and those in the apoplast regions are omitted in this illustration. Arrows indicate directions of turgor exerting. N, nucleus; C, chloroplast; $\mathrm{M}$, mitochondia; m, macromolecule.

subtracting an osmotic potential from a water potential measured by using a homemade isopiestic psychrometer with a fair degree of precision (Nonami et al., 1987; Nonami and Schulze, 1989). Turgor of the trehalose-treated tulip tepals at $7 \mathrm{~d}$ indicated about $0.3 \mathrm{MPa}$ and were maintained at a higher level than that of the control indicating about $0.1 \mathrm{MPa}$ (Table 2). Thus, the trehalose-treated tulip tepal tissues maintained free water than in the control at $7 \mathrm{~d}$ after treatment. From these results, measurements of the physical states of water such as $T_{1}$ and turgor in the flower tissues would indicate that trehalose functioned vacuolar water maintenance (Fig. 1).

\section{EFFECT OF TREHALOSE ON MEMBRANE INTEGRITY OF CUT FLOWERS}

In previous reports, shortening of $T_{1}$ or $T_{2}$ of water protons has been observed in cold-acclimated red osier dogwood stems (Burke et al., 1974), azalea flower buds (Kaku et al., 1984) and winter wheat (Yoshida et al., 1997), and in air-dried Vigna hypocotyls (IwayaInoue et al., 1993). These phenomena are accompanied with a considerable decrease in the water content. The fraction of the long $T_{1}$ component in the tissues of the control flowers decreased during senescence, resulting in a close correlation with the water content (IwayaInoue et al., 1999, 2000). It suggests that a change in long fraction of $T_{1}$ would reflect integrity of vacuolar component and membrane integrity resulting in turgor. In petals of a cut rose flower, membrane fluidity gradually decreased with age (Itzhaki et al., 1990). A similar symptom has been described in many studies of flower senescence (Borochov and Woodson, 1989; Torre et al., 1999). They revealed that a decline in membrane fluidity occurred leading to saturation of fatty acid components in the biomembranes. Daylily (Hemerocallis hybrid) flowers, are insensitive to ethylene, but exogenous ABA prematurely upregulates events that occur during natural senescence, such as the loss of differential membrane permeability, and increases in lipid peroxidation and the induction of proteinase 
and RNase activities (Panavas et al., 1998). The membrane damage of the daylily was supposed to be related to peroxidation of membrane lipids (Panavas and Rubinstein, 1998). The accumulated experimental evidence suggests that a decline in the content of membrane components such as phospholipids in flower senescence. Superoxide radicals are known to induce degradation of membrane lipid in petal tissues. In gladiolus petals, superoxiside dismutase (SOD) and catalase activities which involved in the scavenging of superoxiside radicals in plant systems decreased concomitantly with their wilting (Yamane et al., 1999).

Ion leakage of the control gladiolus petals reached about $90 \%$ of the total leakage in frozen-thawed samples, while the trehalose-treated flowers demonstrated only $50 \%$ of the total leakage (Iwaya-Inoue et al., 1999). It suggests that trehalose protected the membrane integrity and preserved water uptake of the petals for up to $4 \mathrm{~d}$. In the petals treated with distilled water, a disruption in membrane integrity in the parenchyma tissue seems to be disturbed by the water uptake via the flower stalk and thus tends to show a decreased amount of free water. Bakaltcheva et al. (1994) indicated that trehalose protects biological membranes under drought stress, and membrane integrity would help cells maintain turgor. These results implied that a decrease in the water content of the petal tissues during senescence was associated with a reduction in free water, due to a decrease in vacuole volume leading to a decrease in membrane integrity. Trehalose, besides maintaining the membrane bilayer in a liquid crystalline phase, would obstruct an ice formation which would damage the membrane structure in respect to the other disaccharides (Branca et al., 2002). Because a trehalose-water system was characterized by the highest value of the hydration number, the fact revealed an extensive destructuring effect on the adjacent water molecules in the vicinity of the biomembranes.

\section{EFFECTS OF TREHALOSE ON TISSUE VIABILITY AND PROTEIN DEGRADATION OF CUT FLOWERS}

To ascertain tissue viability, a method of tetrazolium salt staining was carried out. Tetrazolium salts such as tetranitroblue tetrazolium (TNBT) and 2,3,5-triphenyl tetrazolium chloride (TTC) are reduced by endogenous dehydrogenase, and purplish-black or pink formazan is observed, respectively (Rosa and Tsou, 1961 ; Pellett and Heleba 1998). Petals of the gladiolus spikes treated with $0.1 \mathrm{M}$ trehalose or distilled water were well stained by TNBT on the 1 st $d$; especially, vascular bundles and adjacent parenchyma cells were markedly stained (Otsubo and Iwaya-Inoue, 2000). Trehalose-treated petals were well stained after $4 \mathrm{~d}$ while no such staining was observed in the control. These results clarified that trehalose preserved the tissue viability of the petal for up to $4 \mathrm{~d}$. The similar effect was observed in trehalosetreated tulip tepal tissues (Table 2). Since the relative water contents in the trehalose-treated cut flowers were greater than those of the control, it was considered that the transfer of water from vessels to the parenchyma tissue occurs normally.

During the process of senescence, chrysanthemum flowers showed the highest respiration rate, great efflux of ions, maximum protease activity, high activity of hydrolytic as well as proteolytic enzymes, and high declines in the fresh mass, the relative water content and the total soluble protein (Elanchezhian and Srivastava, 2001). We indicated trehalose remarkably suppressed protein degradation of gladiolus petal tissues (Table 1). Further, SDS-PAGE revealed that protein bands of the control petal tissues mostly faded out while a band of $28 \mathrm{kD}$ protein was clearly maintained in the lane of trehalose-treated spikes on the 4th $d$ (data not shown). In vitro experiments showed that trehalose in Drosophila melanogaster reduced protein aggregation caused by anoxia (Chen et al., 2002). Additionally, it is suggested that both in a soluble and in a phospholipid environment, accumulation of $1 \mathrm{M}$ trehalose leads to a more heat-stable conformation of $\mathrm{H}^{+}$-ATPase in yeast cells (Felix et al., 1999). When the 
Table 1 Effects of trehalose on viability, petal water status, protein content and sugar accumulation in gladiolus flowers during senescence.

\begin{tabular}{|c|c|c|c|c|}
\hline \multirow{2}{*}{$\begin{array}{l}\text { Gladiolus } \times \text { grandiflora hort. } \\
\quad \text { cv. Fujinoyuki }\end{array}$} & \multicolumn{2}{|c|}{$1 \mathrm{~d}$ after treatment } & \multicolumn{2}{|c|}{$4 \mathrm{~d}$ after treatment } \\
\hline & Control $^{z}$ & Trehalose $^{y}$ & Control & Trehalose \\
\hline \multicolumn{5}{|l|}{ Viability } \\
\hline Wilting score ${ }^{\mathrm{x}}$ & $2.0 \pm 0.0$ & $2.0 \pm 0.2$ & $6.0 \pm 0.0$ & $2.8 \pm 0.8$ \\
\hline TNBT activity & positive & positive & negative & positive \\
\hline \multicolumn{5}{|l|}{ Water status } \\
\hline Water content $\left(\mathrm{g} \mathrm{H}_{2} \mathrm{O} \cdot \mathrm{g}\right.$ dry wt. $\left.{ }^{-1}\right)$ & $14.3 \pm 0.9$ & $14.5 \pm 0.6$ & $3.8 \pm 0.4$ & $8.9 \pm 1.0$ \\
\hline NMR relaxation time, Long $T_{1}(\mathrm{~s})$ & $1.37 \pm 0.11$ & $1.45 \pm 0.15$ & $0.82 \pm 0.09$ & $1.25 \pm 0.10$ \\
\hline NMR relaxation time, Short $T_{2}(\mathrm{~ms})$ & $0.21 \pm 0.04$ & $0.19 \pm 0.02$ & $0.40 \pm 0.02$ & $0.18 \pm 0.03$ \\
\hline Protein concentration $\left(\mathrm{mg} \cdot\right.$ floret $\left.^{-1}\right)$ & $5.08 \pm 0.32$ & $5.17 \pm 0.24$ & $1.60 \pm 0.32$ & $3.95 \pm 1.30$ \\
\hline \multicolumn{5}{|l|}{ Sugar concentration $(\mu \mathrm{M})^{\mathrm{w}}$} \\
\hline Fructose & $77.2 \pm 1.9$ & $156.6 \pm 4.4$ & $121.7 \pm 6.6$ & $263.8 \pm 4.8$ \\
\hline Glucose & $68.1 \pm 0.5$ & $146.7 \pm 1.9$ & $80.4 \pm 2.1$ & $249.2 \pm 7.3$ \\
\hline Sucrose & $4.3 \pm 0.4$ & $9.4 \pm 0.8$ & $11.3 \pm 2.1$ & $24.7 \pm 0.6$ \\
\hline Myo-inositol & $2.0 \pm 0.5$ & $7.3 \pm 1.7$ & $27.8 \pm 4.4$ & $18.1 \pm 2.3$ \\
\hline Trehalose & 0.0 & $19.2 \pm 0.5$ & 0.0 & $13.5 \pm 1.5$ \\
\hline
\end{tabular}

z Control, distilled water.

${ }^{y}$ Trehalose treatment, $100 \mathrm{~mm}$ trehalose.

$\mathrm{x}$ The state of senescence for petals was evaluated daily based on the degree of wilting: 1, half-opened ; , fully opened ; 3 , slightly wilted petal edge ; 4 , slightly wilted whole petal ; 5 , severely wilted whole petal ; 6 , severely wilted and browned whole petal.

${ }^{w}$ Sugar concentrations were indicated on the 1st and 3rd days after treatment. Since petal sugar contents per floret did not change over $3 \mathrm{~d}$, remarkable water loss in the control petals resulted in high mol/L concentration on the 4 th day.

plasma membrane $\mathrm{H}^{+}$-ATPase from Kluyveromyces lactis was freeze-dried in the absence of carbohydrates the activity was lost (Sampedro et al., 1998). They stated that trehalose protected the $\mathrm{H}^{+}$-ATPase activity during freeze-drying and rehydration and that the protective efficiency of carbohydrates was as follows : trehalose $>$ maltose $>$ sucrose $>$ glucose $>$ galactose. Additionally, "protein collapse," manifested in glycerol/water by a decrease in the equilibrium conformational separation between the bound and deoxy states, is completely prevented in trehalose (Sastry and Agmon, 1997). This might be important in understanding the ability of trehalose to protect against the dehydration.

\section{SUGAR UPTAKE IN CUT FLOWERS TREATED WITH TREHALOSE SOLUTION}

In anhydrobiotic organisms the accumulation of the trehalose allows them to survive under severe environmental stresses. Petals of the $100 \mathrm{~mm}$ trehalose-treated gladiolus spikes contained about $150 \mu \mathrm{M}$ fructose and glucose, respectively, while petals containing less than $20 \mu \mathrm{M}$ trehalose on the 1st $\mathrm{d}$ (Table 1). These sugar concentrations were much higher than those in the control. Three days after treatment, fructose and glucose increased two-fold of the value determined at $1 \mathrm{~d}$ after treatment while trehalose concentration slightly decreased. These results suggest that functions of trehalose in cut flowers differ from the severe droughtstressed plants indicating high trehalose accumulation (Bianchi et al. 1993 ; Drennan et al. 1993). In transgenic tobacco plants, tolerance against drought stress was not induced by osmotic adjustment with trehalose (Holmström et al., 1996), since the trehalose concentrations seemed too low for osmotic adjustment, i.e., $\leq 5 \mathrm{~mm}$ in the cytosol. In petals of the $100 \mathrm{~mm}$ trehalose-treated gladiolus spikes contained less than $1 \mathrm{mM}$ in fructose, glucose and trehalose, respectively, on the 3 rd day after treatment. Thus, trehalose treatment seemed not to cause 
Table 2 Effects of trehalose on viability, tepal water status and cell elongation in tulip flower tissues during senescence.

\begin{tabular}{|c|c|c|c|c|}
\hline \multirow{2}{*}{$\begin{array}{l}\text { Tulipa gesneriana L. } \\
\text { cv. Ile de France }\end{array}$} & \multicolumn{2}{|c|}{$1 \mathrm{~d}$ after treatment } & \multicolumn{2}{|c|}{$7 \mathrm{~d}$ after treatment } \\
\hline & Control $^{z}$ & Trehalose $^{\mathrm{y}}$ & Control & Trehalose \\
\hline \multicolumn{5}{|l|}{ Viability } \\
\hline Wilting score ${ }^{\mathrm{x}}$ & $1.3 \pm 0.1$ & $1.4 \pm 0.1$ & $5.3 \pm 0.2$ & $3.2 \pm 0.2$ \\
\hline TNBT staining & positive & positive & negative & positive \\
\hline \multicolumn{5}{|l|}{ Water status } \\
\hline Water content $\left(\mathrm{g} \mathrm{H}_{2} \mathrm{O} \cdot \mathrm{g}\right.$ dry $\left._{\text {wt. }}{ }^{-1}\right)$ & $11.5 \pm 0.0$ & $11.2 \pm 0.0$ & $3.0 \pm 0.1$ & $7.2 \pm 0.0$ \\
\hline NMR relaxation time, Long $T_{1}(\mathrm{~s})$ & $1.10 \pm 0.08$ & $1.26 \pm 0.02$ & $0.87 \pm 0.08$ & $1.15 \pm 0.04$ \\
\hline Turgor $(\mathrm{MPa})$ & $0.32 \pm 0.05$ & $0.34 \pm 0.04$ & $0.14 \pm 0.05$ & $0.28 \pm 0.06$ \\
\hline \multicolumn{5}{|l|}{ Cell size $(\mu \mathrm{m})$} \\
\hline Parenchyma cell length & $157.2 \pm 4.4$ & $150.1 \pm 9.6$ & $172.9 \pm 9.6$ & $173.0 \pm 11.2$ \\
\hline width & $31.0 \pm 1.0$ & $30.5 \pm 1.2$ & $24.2 \pm 1.4$ & $31.3 \pm 0.9$ \\
\hline Guard cell length & $42.5 \pm 1.6$ & $43.8 \pm 1.3$ & $43.3 \pm 1.7$ & $41.9 \pm 1.9$ \\
\hline width & $18.5 \pm 1.5$ & $16.3 \pm 1.1$ & $19.1 \pm 0.8$ & $18.1 \pm 1.2$ \\
\hline
\end{tabular}

${ }^{2}$ Control, $50 \mu \mathrm{M}$ chloramphenicol (CAP).

${ }^{y}$ Trehalose treatment, $50 \mathrm{~mm}$ trehalose with $50 \mu \mathrm{M}$ CAP.

${ }^{x}$ The state of senescence for tepals was evaluated daily based on the degree of wilting and abscission. Life stages of the flower were defined by the following six scores : 1, half-opened ; 2 , fully opened ; 3 , slightly wilted at the tepal edge ; 4 , slightly wilted over half of tepal ; 5 , wilted whole tepal $; 6$, severely wilted and darkened whole tepal with abscission.

osmotic adjustment in cut flower tissues.

Trehalose did not specifically enhance elongation in either parenchyma or guard cells in tepal tissues (Iwaya-Inoue and Takata, 2001) (Table 2). On the contrary, flower diameter and fresh weight of cut roses were markedly increased by $3 \%$ sucrose in combination with 8 hydroxyquinoline sulfate (HQS) (Ichimura et al., 1999). Additionally, a vase solution containing 2\% sucrose and Physan 20, a quaternary ammonium disinfectant (commercial mixture consisting of $10 \% n$-alkyl $\left(\mathrm{C}_{12}-\mathrm{C}_{14}\right)$ dimethylethylbenzyl ammonium chlorides), promoted bud opening, and prolonged the longevity of individual florets of hybrid Limonium (Doi and Reid, 1995). These results suggest that sucrose supplied the energy and carbon skeletons required for bud opening while trehalose may not act as an energy source as sucrose does. Trehalose also suppressed growth and cell wall synthesis in vitro of shoot tips of Cuscuta reflexa Roxb. (Veluthambi et al., 1982). The growth of tissue-cultured soybean (Glycine $\max$ [L.] Merr.) embryos was retarded more on media containing 3\% trehalose than on those containing 3\% sucrose (Ikeda et al., 2000). In Arabidopsis seedlings, growth on trehalose-containing medium leads to an inhibition of root elongation, an accumulation of starch in the shoots, an increased activity of ADP-Glc pyrophosphorylase (AGPase), and an induction of the expression of the AGPase gene, ApL3 (Wingler et al., 2000). These results suggest that an excessive accumulation of trehalose is toxic to plant tissues under optimal conditions. A discovery of genes for trehalose biosynthesis in Arabidopsis and in a range of crop plants suggests that the ability to synthesize trehalose is widely distributed in the plant kingdom (Van Dijck et al., 2002 ; Wingler, 2002). The apparent lack of trehalose accumulation in most plant species is probably due to the presence of trehalase activity (Müller et al., 1995, 2001). Additionally, trehalose-treated gladiolus bracts appeared to have suffered some damage over the course of the $4 \mathrm{~d}$ (Otsubo and Iwaya-Inoue, 2000). Growth of transgenic tobacco was inferior to that of the wild-type when plants were grown under optimal conditions (Holmström et al., 1996; Pilon-Smits et al., 1998). These findings suggest that trehalose and trehalase may play a role in regulating the carbohydrate allocation in plants.

On the other hand, the fact that maintenance of parenchyma cell enlargement was only 
observed in trehalose-treated tulip flowers suggests that trehalose maintained turgor in tepals (Table 2). Marousky (1972) reported that sucrose and 8-hydroxyquinoline citrate (HQC) also improved flower opening, longevity and increased turgidity in Gypsophila. Since it has been suggested that trehalose protects biological membranes under drought stress (Bakaltcheva et al. 1994), membrane integrity would help cells maintain turgor, resulting in reduced water loss in tulip tepals and gladiolus petals. In our experiment, trehalose played an important role in prolonging vase life of cut flowers, though the molecular mechanism by which trehalose might exert an influence on cell functions remains unknown.

\section{EFFECT OF TREHALOSE PLAYING A ROLE IN REGULATING GLASSY STATE OF WATER}

Sano et al. (1999) indicated a dual role for intracellular trehalose in the resistance of yeast cells to water stress; when trehalose content is greater than $2-3 \%$ of the cell dry weight, the amount of bound water was drastically decreased and the viability of the dried cells was increased. This implies that a major portion of the bound water is replaced by trehalose. It is rationalized a water replacement hypothesis, developed to explain the preservation of biomembranes by trehalose; this hypothesis suggests that trehalose forms hydrogen bonds with the membrane polar headgroups, thus replacing the water of hydration at the membrane-fluid interface and maintaining the headgroups at their hydrated position (Lambruschini et al., 2000).

In the trehalose-treated gladiolus petals long $T_{2} \mathrm{~S}$ were determined by CPMG (IwayaInoue et al., 1999) method and short $T_{2}$ s estimated as bound water were detected by the solid echo method (Iwaya-Inoue et al., 2000). The short $T_{2}$ of trehalose-treated gladiolus petals maintained the initial values while that of the control increased on the 4th day after treatment (Table 1). These results suggest that bound water in the petal tissues was also maintained by trehalose treatment. A mobility of water is restricted by the presence of proteins, sugars and biomembranes. The short $T_{2}$ ranged in a $\mu$ s order and the $T_{2}$ is more strongly affected by the concentration of crystalline water binding site and the thickness of the hydration water multilayer. It suggested that since water content was about $90 \%$ per fresh weight basis and trehalose uptake was only $15 \mu \mathrm{M}$, the water status for the flower petals differed from the yeast cells (Sano et al. 1999). The very small quantity of trehalose uptake into the petal tissues may protect dynamic states of water in the cytoplasm (Table 1). Our data suggest that the carbohydrates that are present in the cytoplasm are primary factors contributing to the glassy state (Wolkers et al., 1998). Trehalose has been shown by many workers to be uniquely effective in stabilizing dry or frozen biomolecules, cells and tissues. Crowe et al (1998) indicated that trehalose has a remarkably high glass-transition temperature and thus glass formation is in itself sufficient to stabilize dry biomaterials.

\section{CONCLUSION}

In conclusion, trehalose played an important role to prevent loss of water determined by ${ }^{1} \mathrm{H}$-NMR relaxation times $\left(T_{1}, T_{2}\right)$ and turgor measurements in prolonging cut flowers of ethylene-insensitive plants. Based on the finding that the water contents of the gladiolus petals and tulip tepals of the trehalose-treated cut flowers were greater than those of the controls, it is suggested that transfer of water from vessels to the parenchyma tissue occurs normally. The very small quantity of trehalose uptake into petal tissues seemed to cause neither osmotic adjustment nor energy source in cut flower tissues. The $T_{1}$ and turgor in the flower tissues suggestes that trehalose functioned vacuolar water maintenance, while the short 
$T_{2}$ would indicate the trehalose may protect dynamic states of water in the cytoplasm. Thus, trehalose appears to protect membranes and enzymes and thereby prevent water loss in gladiolus petal and tulip tepal tissues.

This work was supported in part by a Grant-in-Aid (No.11460016) for Scientific Research from the Ministry of Education, Science, Sports and Culture of Japan to M. I. I. We thank Dr. M. Sakurai of the Tokyo Institute of Technology and Hayashibara Co., Ltd., for the gift of trehalose.

\section{REFERENCES}

Bakaltcheva, I., Williams, W., Schmitt, J., Hincha, D. 1994. The solute permeability of thylakoid membranes is reduced by low concentrations of trehalose as a cosolute. Biochem. Biophys. Acta 1189 : $38-44$.

Bianchi, G., Gamba, A., Limiroli, R., Pozzi, N., Elster, R., Salamini, F., Bartels, D. 1993. The unusual sugar composition in leaves of the resurrection plant Myrothamnus flabellifolia. Physiol. Plant. 87 : 223-226.

Bieleski, R. L., Reid, M. S. 1992. Physiological changes accompanying senescence in the ephemeral daylily flower. Plant Physiol. 98 : 1042-1049.

Borochov, A., Spiegelstein, H., Philosophhadas, S. 1997. Ethylene and flower petal senescenceinterrelationship with membrane lipid catabolism. Physiol. Plant. 100 : 606-612.

Borochov, A., WoodsonW. R. 1989. Physiology and biochemistry of flower petal senescence. Hortic. Rev. 11 : 15-43.

Branca, C., Magazu, S., Maisano, G., Migliardo, F., Migliardo, P., Romeo, G., Vorobieva, E. 2002. Hydration properties of disaccharide aqueous solutions. Mol. Cryst. Liq. Cryst. 372 : 25-35.

Bravdo, B., Mayak, S., Gravrieli, Y. 1974. Sucrose and water uptake from concentrated sucrose solution by gladiolus shoots and effect of these treatments on floret life. Can. J. Bot. 52: 1271-1281.

Burke, M. J., Bryant, R. G., Weiser, C. J. 1974. Nuclear magnetic resonance of water in cold acclimating red osier dogwood stem. Plant Physiol. 54 : 392-398.

Celikel, F. G., van Doorn, W. G. 1995. Solute leakage, lipid peroxidation, and protein degradation during the senescence of iris tepals. Physiol. Plant. 94 : 515-521.

Chen, Q. F., Ma, E., Behar, K. L., Xu, T., Haddad, G. G. 2002. Role of trehalose phosphate synthase in anoxia tolerance and development in Drosophila melanogaster. J. Biol. Chem. 277 : 3274-3279.

Crowe, J., Crowe, L., Chapman, D. 1984. Preservation of membranes in anhydrobiotic organisms : the role of trehalose. Science 223 : 209-217.

Crowe, J. H., Crowe, L. M., Carpenter, J. F., and Aurell Wistrom, C. 1987. Stabilization of dry phospholipid bilayers and proteins by sugars. Biochem. J. 242: 1-10.

Crowe, J. H., Carpenter, J. F., Crowe, L. M. 1998. The role of vitrification in anhydrobiosis. Annu. Rev. Physiol. 60 : 73-103.

Doi, M., Reid, M. S. 1995. Sucrose improves the postharvest life of cut flowers of a hybrid Limonium. HortScience 30 : 1058-1060.

Drennan, P. M., Smith, M. T., Goldsworthy, D., van Staden, J. 1993. The occurrence of trehalose in the leaves of the desiccation-tolerant angiosperm Myrothamnus flabellifolius Welw. J. Plant Physiol. 142 : 493-496.

Eason, J. R., Ryan, D. J., Pinkney, T. T., O’Donoghue, E. M. 2002. Programmed cell death during flower senescence : isolation and characterization of cysteine proteinases from Sandersonia aurantiaca, Funct. Plant Biol. 29 : 1055-1064.

Elanchezhian, R., Srivastava, G. C. 2001. Physiological responses of chrysanthemum petals during senescence. Biol. Plant. $44:$ 411-415.

Elbein, A. 1974. The metabolism of $\alpha, \alpha$-trehalose. Adv. Carbohydr. Chem. Biochem. 30: 227-256.

Felix, C. F., Moreira, C. C., Oliveira, M. S., Sola-Penna, M., Meyer-Fernandes, J. R., Scofano, H. M., Ferreira-Pereira, A. 1999. Protection against thermal denaturation by trehalose on the plasma membrane $\mathrm{H}^{+}$-ATPase from yeast-Synergetic effect between trehalose and phospholipid. Environ. Eur. J. Biochem. 266 : 660-664. 
Guerrero, C., Delacalle, M., Reid, M. S., Valpuesta, V. 1998. Analysis of the expression of two thiol protease genes from daylily (Hemerocallis spp.) during flower senescence. Plant Mol. Biol. 36: 565571.

Hanamura, T., Asakawa, N., Inoue, Y., Sakurai, M. 1998. A solid-state ${ }^{31}$ P NMR study of the interaction between trehalose and DPPC bilayer. Chem. Lett. 713-714.

Halevy, A. H., Mayak, S. 1979. Senescence and postharvest physiology of cut flowers, part 1. Hortic. Rev. 1 : 204-236.

Hills, B. P., Remigereau, B. 1997. NMR studies of changes in subcellular water compartmentation in parenchyma apple tissue during drying and freezing. Int. J. Food Sci. Tech. 32 : 51-61.

Holmström, K. O., Mäntylä, E., Welin, B., Mandel, A., Palva, E. T., Tunnela, O. E., Londesborough, J. 1996. Drought tolerance in tobacco. Nature 379: 683-684.

Hottinger, T., De Virgilio, C., Hall, M., Boller, T., Wiemken, A. 1994. The role of trehalose synthesis for the acquisition of thermo-tolerance in yeast. II. Physiological concentration of trehalose increase the thermal stability of proteins in vitro. Eur. J. Biochem. 219: 187-193.

Ichimura, K., Hiraya, T. 1999. Effect of thiosulfate complex (STS) in combination with sucrose on the vase life of cut sweet pea flowers. J. Jpn. Soc. Hortic. Sci. 68 : 23-27.

Ichimura, K., Kojima, K., Goto, R. 1999. Effects of temperature, 8-hydroxyquinoline sulphate and sucrose on the vase life of cut rose flowers. Postharvest Biol. Technol. 15 : 33-40.

Ikeda, T., Iwaya-Inoue, M., Fukuyama, T., Nonami, H. 2000. Trehalose changes hydraulic conductance of tissue-cultured soybean embryos. Plant Biotechnol. 17 : 119-125.

Ishida, N., Kano, H., Kobayashi, T., Hamaguchi T., Yoshida, T. 1987. Estimation of biological activities by NMR in soybean seeds during maturation. Agric. Biol. Chem. 51 : 301-307.

Ishida, N., Koizumi, M., Kano, H. 2000. The NMR microscope : a unique and promising tool for plant science. Ann. Bot. 86 : 259-278.

Itzhaki, H., Borochov, A., Mayak, S. 1990. Age-related changes in petal membrane from attached and detached rose flowers. Plant Physiol. 94 : 1233-1236.

Iwaya-Inoue, M., Yoshimura, K., Yamasaki H., Kaku, S. 1993. Characteristic changes in relaxation times of water protons in Vigna radiata seedlings exposed to temperature stress. Plant Cell Physiol. 34: 705-711.

Iwaya-Inoue, M., Otsubo, M., Watanabe G. 1999. Cellular water status in flower petals during senescence. Cryobiol. Cryotechnol. $45: 21-27$.

Iwaya-Inoue, M., Takata, M., Otsubo, M., Toda, S., Wada, H., Fukuyama, T., Nonami, H. $2000 . \quad$ Role of trehalose in cut flowers of bulbous plants at growth and senescence stages. Cryobiol. Cryotechnol. 46: $108-114$.

Iwaya-Inoue, M., Takata, M. 2001. Trehalose plus chloramphenicol prolongs the vase-life of tulip flowers. HortScience 36 : 946-950.

Kaku, S. 1993. Monitoring stress sensitivity by water proton NMR relaxation times in leaves of azaleas that originated in different ecological habitats. Plant Cell Physiol. 24 : 535-541.

Kaku, S., Iwaya-Inoue, M., Gusta, L. V. 1984. Relationship of nuclear magnetic resonance relaxation time to water content and cold hardiness in flower buds of evergreen azaleas. Plant Cell Physiol. 25: $875-882$.

Kaku, S, Iwaya-Inoue, M. 1990. Factors affecting the prolongation of NMR relaxation times of water protons in leaves of woody plants affected by formation of insect galls. Plant Cell Physiol. 31 : 627637.

Kandror, O., DeLeon, A., Goldberg, A. L. 2002. Trehalose synthesis is induced upon exposure of Escherichia coli to cold and is essential for viability at low temperatures. Proc. Natl. Acad. Sci. U.S.A. 99 : 9727-9732.

Lambruschini, C., Relini, N., Ridi, A:, Cordone, L., Gliozzi, A. 2000. Trehalose interacts with phospholipid polar heads in Langmuir monolayers. Langmuir 16 : 5467-5470.

Lee, C. W. B., Das Gupta, S. K., Mattai, J., Shipley, G. G., A-Mageed, O. H., Makriyannis, A. Griffin, R. G. 1989. Characterization of th $\mathrm{L}_{\lambda}$ phase in trehalose-stabilized dry membranes by solid-state NMR and X-ray diffication. Biochemistry 28 : 5000-5009.

Lehmann, K., Hause, B., Altmann, D., Kock, M. 2001. Tomato ribonuclease LX with the functional endoplasmic reticulum retention motif HDEF is expressed during programmed cell death processes, including xylem differentiation, germination, and senescence. Plant Physiol. 127 : 436-449. 
Mahagamasekera, M. G. P., Leung, D. W. M. 2001. Development of leucine aminopeptidase activity during daylily flower growth and senescence. Acta Physiol. Plant. 23 : 181-186.

Marre, E. 1979. Fusicoccin : A tool in plant physiology. Annu. Rev. Plant Physiol. 30 : 273-288.

Marousky, F. J. 1972. Influence of storage temperature, handling and floral preservatives on postharvest quality of Gypsophyla. Proc. Florida State Hortic. Sci. 85 : 419-422.

McCain, D. C., Selig, T., Govindjee, C., Markley, L. J. 1984. Some plant leaves have orientationdependent EPR and NMR spectra. Proc. Natl. Acad. Sci. U.S.A. 81 : 748-852.

Müller, J., Boller, T., Wiemken, A. 1995. Trehalose and trehalase in plants: recent developments. Plant Sci. 112 : 1-9.

Müller, J., Aeschbacher, R. A., Wingler, A., Boller, T., Wiemken, A. 2001. Trehalose and trehalase in Arabidopsis. Plant Physol. 125 : 1086-1093.

Nonami, H., Boyer, J. S., Steudle, E. 1987. Pressure probe and isopiestic psychrometer measure similar turgor. Plant Physiol. 83 : 592-595.

Nonami, H., Schulze, E.-D. 1989. Cell water potential, osmotic potential, and turgor in the epidermis and mesophyll of transpiring leaves: Combined measurements with the cell pressure probe and nanoliter osmometer. Planta 177 : 35-46.

Otsubo, M., Iwaya-Inoue, M. 2000. Trehalose delays senescence in cut gladiolus spikes. HortScience 35: $1107-1110$.

Panavas, T., Rubinstein, B. 1998. Oxidative events during programmed cell death of daylily (Hemerocallis hybrid) petals. Plant Sci. 133 : 125-138.

Panavas, T., Walker, E. L., Rubinstein, B. 1998. Possible involvement of abscisic acid in senescence of daylily petals. J. Exp. Bot. 49: 1987-1997.

Panavas, T., LeVangie, R., Mistler, J., Reid, P. D., Rubinstein, B. 2000. Activities of nucleases in senescing daylily petals. Plant Physiol. Biochem. 38 : 837-843.

Pellett, N. E., Heleba, D. A. 1998. Comparing callus growth with discoloration and electrical conductivity as measures of stem injury after freezing woody plants. J. Am. Soc. Hortic. Sci 123 : 826-831.

Pilon-Smits, E. A. H., Terry, N., Sears, T., Kim, H., Zayed, A., Hwang, S., van Dun, K., Voogd, E., Verwoerd, T. C., Krutwagen, R. W. H. H., Goddijn, O. J. M. 1998. Trehalose-producing transgenic tobacco plants show improved growth performance under drought stress. J. Plant Physiol. 152: 525532.

Reid, M. S., Wu, M.-J. 1992. Ethylene and flower senescence. Plant Growth Regul. 11 : 37-43.

Rosa, C. G., Tsou, K. C. 1961. Use of tetrazolium compounds in oxidative enzyme histo- and cytochemistry. Nature 192 : 990-991.

Sampedro, J. G., Guerra, G., Pardo, J. P., Uribe, S. 1998. Trehalose-mediated protection of the plasma membrane $\mathrm{H}^{+}$-ATPase from Kluyveromyces lactis during freeze-drying and rehydration. Cryobiology 37 : 131-138.

Sano, F., Asakawa, N., Sakurai, M. 1999. A dual role for intracellular trehalose in the resistance of yeast cells to water stress. Cryobiology 39: 80-87.

Sastry, G. M., Agmon, N. 1997. Trehalose prevents myoglobin collapse and preserves its internal mobility. Biochemistry $36: 7097-7108$.

Snaar, J. E. M., Van As, H. 1992. Probing water compartments and membrane permeability in plant cell by ${ }^{1} \mathrm{H}-\mathrm{NMR}$ relaxation measurements. Biophys. J. 63 : 1654-1658.

Sulyok, E., Nyul, Z., Bogner, P., Berenyi, E., Repa, I., Vajda, Z., Doczi, T., Sedin, G. 2001. Brain water and proton magnetic resonance relaxation in preterm and term rabbit pups: Their relation to tissue hyaluronan. Biol. Neonate. 79:67-72.

Taverner, E. A., Letham, D. S., Wang, J., Cornish, E. 2000. Inhibition of carnation petal inrolling by growth retardants and cytokinins. Aust. J. Plant Physiol. 27 : 357-362.

Torre, S., Borochov, A., Halevy, A. H. 1999. Calcium regulation of senescence in rose petals. Physiol. Plant. 107 : 214-219.

Van Dijck, P., Mascorro-Gallardo, J. O., De Bus, M., Royackers, K., Iturriaga, G., Thevelein, J. M. 2002. Truncation of Arabidopsis thaliana and Selaginella lepidophylla trehalose-6-phosphate synthase unlocks high catalytic activity and supports high trehalose levels on expression in yeast. Biochem. J. 366 (Part 1): 63-71.

van Doorn, W. 1997. Water relations of cut flowers. Hortic. Rev. 18: 1-85.

Veluthambi, K., Mahadevan, S., Maheshwari, R. 1982. Trehalose toxicity in Cuscuta reflexa. Plant 
Physiol. 70 : 686-688.

Wagstaff, C., Leverentz, M. K., Griffiths, G., Thomas, B., Chanasut, U., Stead, A. D., Rogers, H. J. 2002. Cysteine protease gene expression and proteolytic activity during senescence of Alstroemeria petals. J. Expt. Bot. 53 : 233-240.

Wingler, A. 2002. The function of trehalose biosynthesis in plants. Phytochemistry 60: 437-440.

Wolkers, W. F., Oldenhof, H., Alberda, M., Hoekstra, F. A. 1998. A Fourier transform infrared microspectroscopy study of sugar glasses -application to anhydrobiotic higher plant cells. Biochem. Biophys. Acta-General Subjects 1379: 83-96.

Woltering, E. J., van Doorn, W. G. 1988. Role of ethylene in senescence of petals morphological and taxonomical relationships. J. Exp. Bot. 39: 1605-1606.

Yamane, K., Kawabata, Fujishige, N. 1999. Changes in activities of superoxide dismutase, catalase and peroxidase during senescence of gladiolus florets. J. Jpn. Soc. Hortic. Sci. 68 : 798-802.

Yoshida, M., Abe, J., Moriyama, M., Shimokawa, S., Nakamura., Y. 1997. Seasonal changes in the physical state of crown water associated with freezing tolerancein winter wheat. Physiol. Plant. 99 : 363-370. 